\title{
THE ROLE OF "KERAPATAN ADAT NAGARI (KAN)" IN SOLVING THE DISPUTE OF COMMUNAL LAND
}

\section{PERAN KERAPATAN ADAT NAGARI (KAN) DALAM MENYELESAIKAN SENGKETA TANAH ULAYAT ${ }^{*}$}

\author{
Faisal \\ Sekolah Tinggi Ilmu Hukum Putri Maharaja Payakumbuh \\ E-mail : faisal.buchari61@gmail.com
}

\begin{abstract}
According to miankabaunese's traditional law, when a dispute or disagreement occurs in a community, it is resolved by consensus among members of the clan or clan leaders which ends in the fellowship of local custom assosiation called with "Kerapatan Adat Nagari (KAN)". The problem formulation of this research is; what is the role of Kerapatan Adat Nagari (KAN) in resolving communal land (tanah Ulayat) disputes in one of local villager called Kenagarian Bukik Sikumpa, Lima Puluh Kota Regency? and how the efforts of Kerapatan Adat Nagari (KAN) to overcome obstacles in resolving communal land disputes in Kenagarian Bukik Sikumpa, Lima Puluh Kota Regency. The method of the research is an empirical juridical approach. The conclusion of research is that the role of Kerapatan Adat Nagari (KAN) of Bukik Sikumpa of Lima Puluh Kota district is as the mediator any disputes where the provisions of Perda No. 7 of 2018 as the legal basis. This provision declares that every local villagers have to prioritie in conducting local wisdom deliberation as solving problem among the family, community, and tribal levels. Kerapatan Adat Nagari (KAN) acts as an intermediary in resolving disputes if these three domains of local deliberation have been taken by the disputing families. Due to local religious philosophy "Adat basandi syarak, syarak basandi Kitabullah", every customari chiefs whether they are members of the Kerapatan Adat Nagari (KAN) or who are not, should increase the sense of justice and be wiser for people's trust restoration.
\end{abstract}

Keywords: Role; Nagari Adat Density; Disputes; Ulayat Land.

\begin{abstract}
Abstrak
Menurut hukum adat Minangkabau bila terjadinya sengketa atau perselisihan dalam suatu kaum diselesaikan secara mufakat diantara anggota kaum atau penghulu kaum yang berakhir pada Kerapatan Adat Nagari (KAN). Adapun rumusan masalah dari penelitian ini adalah: bagaimanakah peran Kerapatan Adat Nagari (KAN) dalam menyelesaikan sengketa tanah ulayat di Kenagarian Bukik Sikumpa Kabupaten Lima Puluh Kota ?, apa kendala Kerapatan Adat Nagari (KAN) dalam menyelesaikan sengketa tanah ulayat di Kenagarian Bukik Sikumpa Kabupaten Lima Puluh Kota? dan bagaimana upaya Kerapatan Adat Nagari (KAN) untuk mengatasi kendala dalam menyelesaikan sengketa tanah ulayat di Kenagarian Bukik Sikumpa Kabupaten Lima Puluh Kota. Metode penelitian ini adalah menggunakan pendekatan yuridis empiris. Sebagai kesimpulan dari penelitian ini adalah: peran KAN Bukik Sikumpa Kabupaten Lima Puluh Kota, adalah sebagai penengah atas setiap sengketa berdasarkan ketentuan Perda Nomor 7 tahun 2018 tentang Nagari dimana langkah-langkah penyelesaian wajib didahului dengan musyawarah di tingkat keluarga, kaum, dan pesukuan. KAN dapat bertindak sebagai penengah dalam menyelesaikan sengketa apabila ketiga langkah tersbut telah di tempuh para keluarga yang bersengketa. yang berlandaskan filosofi "Adat basandi syarak, syarak basandi kitabullah" dan agar pemuka adat, baik yang merupakan anggota KAN atau yang bukan hendaknya meningkatkan rasa keadilan dan lebih bijaksana sehingga dapat mengembalikan kepercayaan masyarakat.
\end{abstract}

Kata kunci : Peran, Kerapatan Adat Nagari, Sengketa, Tanah Ulayat.

\footnotetext{
* Naskah diterima: 3 Maret 2021, direvisi: 20 Maret 2021, disetujui untuk terbit: 27 Maret 2021

Doi: $10.3376 /$ jch.v6i2.340
} 


\section{PENDAHULUAN}

Lembaga peradilan adat di Indonesia khususnya di Sumatera Barat yang dikenal dengan alam Minangkabau sudah tumbuh dan berkembang, dipelihara serta dipatuhi oleh masyarakat dalam kehidupan bernegara yang sampai saat ini masih ditemukan dalam praktek terutama dalam penyelesaian sengketa adat $(H$. Idurs Hakimi Dt. R. Penghulu, 2013) Pengertian peradilan adat menurut adat di Minangkabau adalah proses, cara mengadili dan menyelesaikan yang dilakukan oleh sejenis Badan atau lembaga di luar peradilan dalam UndangUndang Pokok-Pokok Kekuasaan Kehakiman.

Sebagaimana diketahui bahwa sengketa tanah ulayat merupakan sengketa yang mayoritas terjadi di Sumatera Barat dan yang sangat dominan terjadi di nagari-nagari yang ada di Sumatera Barat, ini dilatar belakangi oleh perkembangan kebutuhan akan tanah mengalami peningkatan luar biasa, karena disebabkan oleh adanya : kepadatan penduduk yang semakin bertambah Dengan bertambahnya penduduk dari tahun ke tahun pasti kebutuhan untuk rumah semakin meningkat pula.

Menurut hukum adat Minangkabau bila terjadinya sengketa atau perselisihan dalam suatu kaum diselesaikan secara mufakat diantara anggota kaum atau penghulu kaum yang berakhir pada Kerapatan Adat Nagari (KAN). Dalam pasal 1angka 10 Perda Nomor 2 Tahun 2007 Tentang Pokok-Pokok Pemerintahan Nagari dijelaskan KAN adalah;
"Lembaga Kerapatan dari Ninik Mamak yang telah ada dan diwarisi secara turun temurun sepanjang adat dan berfungsi memelihara kelestarian adat serta menyelesaikan perselisihan sako dan pusako".

Mengenai fungsi dan tugas KAN terdapat dalam pasal 7 Peraturan Daerah Popinsi Sumatera Barat Nomor 7 tahun 2019 Tentang Nagari, sedangkan jenis sengketa atau jenis perkara yang diselesaikan oleh KAN adalah sebagai berikut :

1. Sengketa mengenai gelar (sako).

2. Sengketa mengenai harta (pusako)

Sengketa mengenai gelar (sako) adalah sengketa yang berkaitan dengan gelar yang diterima secara turun temurun di dalam suatu kaum yang fungsinya adalah sebagai kepala kaum adat (penghulu) dan sako ini bersifat turun temurun semenjak dulu sampai sekarang, menurut garis ibu lurus ke bawah Sedangkan sengketa mengenai harta pusaka (pusako) adalah sengketa yang berkaitan dengan harta pusaka tinggi seperti sawah ladang, banda buatan, labuah tapian, rumah tango, pandam pakuburan, hutan tanah yang belum diolah.

Masalah sengketa ini diselesaikan secara adat melalui musyawarah dan mufakat para Ninik Mamak atau fungsionaris adat, apabila masalah ini tidak bisa diselesaikan secara adat maka melalui pengadilan penyelesaian sengketa ini diselesaikan. Keistimewaan negeri (nagari) di Minangkabau terlihat pada 
susunan masyarakatnya yang terdiri dari paling sedikit empat suku, masing-masing suku terdiri dari beberapa kaum, masingmasing suku terdiri oleh seorang penghulu. Himpunan penghulu di suatu nagari disebut Ninik Mamak.

Menurut adat Minangkabau tanah ulayat dibagi atas tanah ulayat kaum, tanah ulayat suku, salah satu tugas Penghulu adalah memelihara, mengurus dan mengatur pemanfaatan tanah ulayat suku atau kaum, yang disebut juga Tanah Pusako Tinggi, selanjutnya berkewajiban mewariskan kepada generasi berikutnya dalam keadaan utuh. Apabila terjadi sengketa tanah ulayat tersebut penghulu berkewajiban menyelesaikannya.

Intisari dari Hukum Adat yang tersimpul dalam Hak Ulayat adalah: bahwa Hak Ulayat itu harus dipergunakan untuk kepentingan masyarakat yang mendukungnya dan sekali-sekali bukanlah untuk kepentingan perseorangan, pada prinsipnya hak ulayat tidak mungkin menghambat pembangunan, tetapi justru harus dipergunakan untuk pembangunan (Nova Yarsina, 2018)

Pada dasarnya tanah ulayat sebagai harta pusaka tinggi adalah hak bersama. Jika tanah ulayat yang telah dilakukan peralihan hak, berdasarkan surat jual beli saja, dapat dituntut karena dianggap belum memiliki hak penguasaan penuh, karena kebanyakan dalam surat jual beli dibawah tangan klausanya tidak dibuat secara jelas hanya tertera jual beli sebidang kebun yang dapat diartikan tidak beserta tanahnya. Lain halnya dengan orang yang menerima hibah dari pemegang hak ulayat (Ratih Agustin Wulandari, Muhammad Sukron, Raimon Efendi, 2020).

Di nagari secara bersama-sama Ninik Mamak mempunyai tugas untuk memelihara, mengurus dan mengatur pemanfaatan tanah ulayat nagari baik bagi anak nagari yang ingin memanfaatkannya maupun bagi pihak lain yang ingin menanam modalnya. Baik penghulu maupun Ninik Mamak dalam melaksanakan tugasnya memelihara dan mengatur pemanfaatan tanah ulayat serta penyelesaian sengketa diharapkan mempunyai sifat-sifat yang ditentukan oleh adat, sifatsifat tersebut adalah sebagai berikut: sifat siddik (benar), tabliq (menyampaikan), amanah (kepercayaan), dan fathanah (kesempurnaan cerdik dalam memelihara Agama dan harta). Cerdik artinya orang yang mampu membayar hutang, membayar hutang kepada anak-kemanakan, membayar hutang terhadap korong kampung, membayar hutang kepada nagari dan membayar hutang kepada Tuhannya. Cerdik itu ada beberapa macam, yaitu cerdik jawab menjawab, cerdik kajimengaji, cerdik kecek-mengecek, cerdik tipu dayo, cerdik baraka, cerdik barang tiap-tiap sesuatu (Ahyuni Yunusdan Ahmad Ali Muddin, 2019)

Kerapatan Adat Nagari (KAN) merupakan lembaga adat tertinggi di nagari, tempat berhimpunnya penghulu di nagari yang disebut Ninik Mamak. Lembaga adat ini keberadaanya seiring dengan berdirinya suatu nagari dengan 
nama yang berbeda-beda di masingmasing nagari. Keberadaan Kerapatan Adat Nagari sangat penting artinya, karena selain, mengurus, memelihara dan mengatur pemanfaatan tanah ulayat nagari, di samping itu Kerapatan Adat Nagari berperan untuk menyelesaikan sengketa tanah ulayat suku atau kaum. Ada berbagai pendapat yang berkembang dalam masyarakat tentang penyelesaian sengketa tanah ulayat, ada yang berpendapat sebaiknya sengketa tanah ulayat cukup diselesaikan oleh KAN setempat, putusan KAN mengikat kedua belah pihak. Perkara tersebut tidak perlu diajukan ke pengadilan, sebab pandangan mereka berperkara ke pengadilan kedua belah pihak akan rugi, seperti petua orang tua-tua, nan kalah jadi abu, nan menang jadi baro (Nurullah, 1999)

Di lain pihak menyatakan bahwa sengketa tanah ulayat terlebih dulu diselesaikan oleh KAN setempat, apabila para pihak yang bersengketa tidak merasa puas, dapat mengajukan ke pengadilan. Adapula yang berpendapat, sengketa tanah ulayat tak perlu diselesaikan oleh KAN setempat, para pihak langsung mengajukan ke pengadilan, alasan mereka berdasarkan pengalaman. Perkara tanah ulayat, yang diajukan ke KAN, biasanya KAN tidak mau menyelesaikannya.

Menurut sengketa tanah yang berasal dari hak atas tanah pusako tinggi atau tanah ulayat inilah yang banyak menimbulkan sengketa tanah di dalam masyarakat hukum adat. Adapun penyebab timbulnya masalah antara lain karena kurang jelasnya batas sepadan tanah ulayat, kurangnya kesadaran masyarakat hukum adat dalam pendaftaran tanah dan tidak berperannya mamak kepala waris dalam kaumnya.

Penyelesaian sengketa dalam peradilan KAN selalu diusahakan secepat mungkin, untuk menghindari keresahan dalam masyarakat. Tidak jarang terjadi dalam peradilan KAN Kenagarian Bukik Sikumpa Kabupaten Lima Pulih Kota, suatu keputusan diambil tiga kali sidang, tetapi cepat atau lambatnya keputusan terhadap sebuah perkara akan sangat ditentukan dan tergantung oleh kasus yang akan diselesaikan, merupakan suatu keputusan (vonis) bersifat tetap atau hasil akhir suatu persengketaan.

Jenis dan Jumlah Kasus yang ditangani KAN di Kenagarian Bukik Sikumpa Kabupaten Lima Puluh Kota 2018 s/d 2020:

\begin{tabular}{|c|c|c|c|c|}
\hline No & Jenis Kasus & 2018 & 2019 & 2020 \\
\hline 1 & Sako & 1 & 1 & 2 \\
\hline 2 & Sengketa Ulayat & 2 & 4 & 5 \\
\hline 3 & Warisan & 2 & 1 & 2 \\
\hline & Jumlah & 5 & 6 & 9 \\
\hline
\end{tabular}

Sumber Data : KAN Kenagarian Bukik Sikumpa Kabupaten Lima Puluh Kota 
Berdasarkan tabel diatas, dalam kenyataannya di Kenagarian Bukik Sikumpa Kabupaten Lima Puluh Kota kasus sengketa tanah ulayat dari tahun 2018 sampai tahun 2020 meningkat setiap tahunnya. Oleh karena itulah penulis tertarik melakukan penelitian mengenai penyelesaian sengketa tanah ulayat ini dengan mengangkatnya ke dalam sebuah skripsi dengan judul : "Peran Kerapatan

$\begin{array}{lrr}\text { Adat Nagari } & (\text { KAN }) & \text { dalam } \\ \text { Menyelesaikan } & \text { sengketa } & \text { Tanah } \\ \text { Ulayat". } & & \end{array}$

\section{METODE PENELITIAN}

Dalam penelitian ini penulis menggunakan metode pendekatan yuridis empiris yang berdasarkan ketentuanketentuan perundang-undangan yang berlaku dikaitkan dengan teori hukum serta melihat realita yang terjadi di masyarakat. Pelitian ini bersifat Deskriptif, yaitu penelitian yang memberikan data tentang sesuatu atau gejala-gejala sosial yang berkembang di tengah-tengah masyarakat sehingga dengan adanya penelitian ini diharapkan dapat memperoleh gambaran yang menyeluruh, lengkap dan sistematis tentang objek yang akan di teliti. Setelah semua data berhasil dikumpulkan berdasarkan penelitian yang dilakukan di lapangan, maka data tersebut disatukan untuk kelanjutan diolah sedemikian rupa secara sistematik. Untuk itu digunakan analisa kualitatif, yaitu hasil penelitian kepustakaan akan dipergunakan untuk menganalisa data yang diperoleh dari lapangan dan kemudian data primer dan data sekunder dianalisa secara kualitatif untuk menjawab permasalahan dalam penelitian ini. Dari bahan dan data yang telah terkumpul dari penelitian tersebut di atas, maka penulis akan menganalisa secara deskriptif yakni membandingkan antara teori dengan prakteknya di lapangan, sehingga diperoleh suatu kesimpulan yang induktif, yaitu suatu kesimpulan dari yang khusus kepada yang umum.

\section{HASIL DAN PEMBAHASAN}

\section{Peran Kerapatan Adat Nagari (KAN) dalam Menyelesaikan Sengketa Tanah Ulayat di Kenagarian Bukik Sikumpa Kabupaten Lima Puluh Kota}

Berdasarkan wawancara dengan Bapak S. Datuak Paduko Sati sebagai ketua KAN di Kenagarian Bukik Sikumpa Kabupaten Lima Puluh Kota mengenai Peran Kerapatan Adat Nagari (KAN) dalam Menyelesaikan Sengketa Tanah Ulayat di Kenagarian Bukik Sikumpa Kabupaten Lima Puluh Kota adalah sebagai berikut:

1. Proses penyelesaian sengketa tanah diselesaikan dengan secara adat minangkabau bajanjang naik, batanggo turun dengan urutannya sebagai berikut:

a. Awalnya diselesaikan pihak yang bersengketa saja, jika tidak mencapai kata sepakat, para pihak mengadukan masalah itu kepada ninik mamak adat masing- masing agar dicari jalan penyelesaiannya.

b. Jika para pihak masih ada yang belum puas atas kesimpulan yang 
Faisal: Peran Kerapatan Adat Nagari (KAN) Dalam Menyelesaikan Sengketa Tanah Ulayat

di ambil dengan para ninik mamak adat, maka sengketa dapat diajukan ke lembaga Kerapatan Adat dan Nagari Kenagarian Bukik Sikumpa Kabupaten Lima Puluh Kota.

2. Kerapatan adat dan nagari menyelesaikan sengketa adat (sako dan pusako) di Kenagarian Bukik Sikumpa Kabupaten Lima Puluh Kota dalam bentuk perdamaian sepanjang adat lebih mengutamakan musyawarah untuk mencapai mufakat.

3. Jika putusan Majelis Perdamaian Kerapatan Adat dan Kenagarian Bukik Sikumpa Kabupaten Lima Puluh Kota tidak sesuai dengan kehendak para pihak atau ada pihak yang merasa dirugikan maka para pihak yang bersengketa boleh mengajukan sengketa ini ke Pengadilan Negeri Kabupaten Lima Puluh Kota. (S. Datuak Paduko Sati, 2020)

Jadi peran KAN Bukik Sikumpa Kabupaten Lima Puluh Kota, adalah sebagai penengah atas setiap sengketa berdasarkan ketentuan Perda Nomor 7 tahun 2018 Tentang Nagari dimana langkah-langkah penyelesaian wajib didahului dengan musyawarah di tingkat keluarga, kaum, dan pesukuan. KAN dapat bertindak sebagai penengah dalam menyelesaikan sengketa apabila ketiga langkah tersbut telah di tempuh para keluarga yang bersengketa tapi pada kenyataannya dalam melaksanakan peran tersebut peran tersebut ditemui kendalakendala.

Peranan KAN dalam Penyelesaian Sengketa Tanah Ulayat di Minangkabau Menurut ajaran Adat Minangkabau apabila terjadi suatu sengketa dalam kaum masyarakat hukum adat diselesaikan oleh mamak kepala waris dalam kaum (Titin Fatimah dan Hengki Andora, 2018)

Kemudian bila putusan tidak memuaskan salah satu pihak maka diselesaikan dalam Kerapatan Adat Nagari yang bersangkutan, sesuai dengan Peraturan Daerah Nomor 7 Tahun 2018 Tentang Nagari Tugas dan wewenang KAN secara rinci diatur dalam Peraturan Daerah Nomor 7 tahun 2018 Tentang Nagari dimana dalam Pasal 7 sebagai berikut: "Kerapatan Adat Nagari mempunyai:

(1) Tugas sebagai berikut :

a. Mengawasi penyelenggaraan Pemerintahan Nagari oleh Kapalo Nagari;

b. Menyusun peraturan Nagari bersama Kapalo Nagari; dan

c. Membahas dan menyepakati Rancangan Peraturan Nagari tentang Anggaran Pendapatan dan Belanja Nagari.

(2) Kerapatan Adat Nagari mempunyai wewenang sebagai berikut :

a. Memilih dan mengangkat Kapalo Nagari secara musyawarah dan mufakat;

b. Menyalurkan aspirasi masyarakat Nagari;

c. Melakukan pengawasan terhadap pelaksanaan adat istiadat dan budaya Nagari;

d. Meminta pertanggungjawaban 
pelaksanaan Pemerintahan Nagari kepada Kapalo Nagari; dan

e. Melestarikan nilai-nilai adat dan budaya sesuai Adat Salingka Nagari.

Penyelesaian sengketa dalam peradilan KAN selalu diusahakan secepat mungkin, untuk menghindari keresahan dalam masyarakat. Tidak jarang terjadi dalam peradilan KAN Kenagarian Bukik Sikumpa suatu keputusan diambil tiga kali sidang, tetapi cepat atau lambatnya keputusan terhadap sebuah perkara akan sangat ditentukan dan tergantung oleh kasus yang akan diselesaikan, merupakan suatu keputusan (vonis) bersifat tetap atau hasil akhir suatu persengketaan.

Adapun hasil wawancara peneliti dengan Datuak Mangkudun sebagai anggota KAN di Kenagarian Bukik Sikumpa Kabupaten Lima Puluh Kota mengenai Prosedur persidangan sampai dengan pengambilan keputusan, sebagai berikut:

a. Pemanggilan pihak penggugat yang mengajukan gugatan.

b. Setelah pemanggilan itu dirundingkan oleh ninik mamak pengadilan adat.

c. Ditanya masing-masing mamak kepala waris dalam sidang oleh anggota sidang untuk diketahui asal usul obyek sengketa, duduk masalah, keinginan pihak penggugat, dsb.

d. Ditanya mau diselesaikan oleh pengadilan adat atau tidak. Begitu juga untuk pihak kedua (tergugat) sama bunyinya sebagaimana hal diatas. e. Kalau mau diselesaikan oleh KAN, baru bukti-bukti diseleksi dan dikaji oleh KAN dengan ketentuan sidang:

1. Tiga kali sidang untuk penggugat

2. Dipanggil pihak kedua sebagai tergugat, juga sama tiga kali sidang sebagaimana penggugat

3. Setelah itu dipertemukan lagi antara penggugat dan tergugat, terjadi daksaan dan jawabanjawaban serta tangkisan yang diajukan selama persidangan berlangsung.

4. Bukti-bukti yang diajukan baik tertulis berupa surat maupun berupa keterangan saksi yang dikemukakan dalam persidangan

5. Ninik mamak turun ke lapangan, ke tempat obyek perkara

6. Dihadiri oleh saksi-saksi sepadan yang berperkara serta Kepala Rukun Tetangga (RT) dan Lurah

f. Dipanggil lagi penggugat dan tergugat oleh KAN, bagaimana rasanya karena ibarat pepatah "sudah siang hari, sudah nampak bulan" telah jelas dan nyata persoalannya, baru KAN memberikan keputusan (vonis) berupa kesimpulan.

Keputusan atau kesimpulan yang diambil majelis hakim dalam KAN dapat berupa :

1. Mengabulkan gugatan, jika gugatan terang (jelas)

2. Memenangkan tergugat jika gugatan tidak terang

3. Jika dalam perkara itu keterangan para pihak sama kuat maka dianjurkan untuk melaksanakan pembagian harta tersebut sama banyak 
4. Hukum bersumpah, jika persengketaan pembagian harta sama banyak tidak dapat dilakukan karena para pihak tidak mau melaksanakan, maka melalui sumpah ini salah satu pihak akan melepaskan harta tersebut. (Datuak Mangkudun, 2020).

Majelis Hakim dalam pengadilan KAN tidak dapat memaksanakan keputusannya, disamping itu juga dibuka atau terbuka kesempatan bagi para pihak yang merasa tidak puas untuk mengajukan perkaranya ke Pengadilan Negeri (S. R. Fatmi and U. Jember, 2018)

Bentuk-bentuk Kasus Sengketa yang masuk pada KAN dKenagarian Bukik Sikumpa Kabupaten Lima Puluh Kota berdasarkan ketentuan Peraturan Daerah Nomor 7 Tahun 2018 tentang Nagari Fungsi menyatakan bahwa bahwa pada Pasal 15 menyatakan:

(1) Pada setiap Nagari, Kerapatan Adat Nagari membentuk Peradilan Adat Nagari sebagai lembaga penyelesaian sengketa masyarakat tertinggi di Nagari sesuai adat salingka Nagari.

(2) Sebelum sengketa sebagaimana dimaksud pada ayat diselesaikan oleh Peradilan Adat Nagari, harus diselesaikan terlebih dahulu pada tingkat keluarga, paruik, kaum dan/atau suku secara bajanjang naiak batanggo turun.

(3) Peradilan Adat Nagari sebagaimana dimaksud pada ayat (1) mempunyai tugas sebagai berikut:

a. Menyelesaikan sengketa sako dan pusako secara bajanjang naiak batanggo turun melalui proses perdamaian;

b. Penyelesaian perkara perdata adat melalui musyawarah dan mufakat berdasarkan kesepakatan dalam sidang majelis Kerapatan Adat Nagari yang merupakan "kato putuih" untuk dipedomani oleh lembaga peradilan ; dan

c. Memberi sanksi adat kepada anggota masyarakat yang melanggar Hukum Adat sesuai dengan ketentuan Adat Salingka Nagari.

Jadi Kerapatan Adat Nagari yang selanjutnya disebut KAN adalah Lembaga Kerapatan dari Ninik Mamak yang telah ada dan diwarisi secara turun temurun sepanjang adat dan berfungsi memelihara kelestarian adat serta menyelesaian perselisihan sako dan pusako" (Amran, 2017).

Bentuk-bentuk kasus pada masyarakat hukum adat di Minangkabau meliputi kasus-kasus yang berkaitan dengan Sako (yakni sengketa gelar), Pusako (yakni sengketa Tanah Ulayat/tanah adat), dan warisan.

Sementara kasus yang ditangani KAN di Kenagarian Bukik Sikumpa Kabupaten Lima Puluh Kota dalam kurun waktu 2018-2020 terdiri dari kasus Sako, Pusako, hal tersebut dapat dilihat pada tabel dibawah ini: 


\begin{tabular}{|c|c|c|c|c|}
\hline No & Jenis Kasus & $\mathbf{2 0 1 8}$ & $\mathbf{2 0 1 9}$ & $\mathbf{2 0 2 0}$ \\
\hline 1 & Sako & $\mathbf{1}$ & $\mathbf{1}$ & $\mathbf{2}$ \\
\hline 2 & Sengketa Ulayat & 2 & 4 & 5 \\
\hline 3 & Warisan & 2 & 1 & 2 \\
\hline & Jumlah & 5 & 6 & 9 \\
\hline
\end{tabular}

Sumber Data : KAN Kenagarian Bukik Sikumpa, Kabupaten Lima Puluh Kota

Dari data tabel diatas, setelah peneliti mengadakan wawancara lanjutan dengan Bapak S. Datuak Paduko Sati sebagai ketua KAN di Kenagarian Bukik Sikumpa Kabupaten Lima Puluh Kota pada hari Kamis Tanggal 12 Desember 2019, Pukul 11.00 WIB yang menjelas kan bahwa :kasus tanah ulayat yang telah diselesaikan pada tingkat KAN di Kenagarian Bukik Sikumpa adalah sebagai berikut:

1. Tahun 2018 kasus tanah ulayat berjumlah : 2 kasus.

2. Tahun 2019 kasus tanag ulayat berjumlah : 4 kasus.

3. Tahun 2020 kasus tanah ulayat berjumlah : 6 kasus.

Maka kenyataannya yang dilanjutkan kepengadilan Negeri Kabupaten Lima Pulih Kota adalah sebagai berikut:

1. Tahun 2018 kasus tanah ulayat berjumlah : 1 kasus.

2. Tahun 2019 kasus tanag ulayat berjumlah : 3 kasus.

3. Tahun 2020 kasus tanah ulayat berjumlah : 4 kasus (Datuak Paduko Sati, 2020).

Dari hasil wawancara penulis dengan ketua KAN Kenagarian Bukik Sikumpa di atas penulis berkesimpulan bahwa kurangnya peran dari anggota KAN dengan adanya kasus Tanah ulayat walaupun telah diselesaikan pada tingkat KAN Kenagarian Bukik Sikumpa, tapi masih dilanjutkan kePengadilan Negeri Kabupaten Lima Puluh Kota.

Jadi Kenagarian Bukik Sikumpa Kabupaten Lima Puluh Kota seperti juga nagari-nagari lain di Minangkabau mempunyai lembaga Kerapatan Adat Nagari dengan prinsip duduk dengan musyawarah, sedangkan Kenagarian Bukik Sikumpa Kabupaten Lima Puluh Kota menganut kelarasan Koto Piliang, namun Kerapatan Adat Nagari, khususnya dalam proses penyelesaiannya, menyelesaikan sengketa secara musyawarah duduk bersama-sama sehingga keputusan didapat atas musyawarah mufakat, bukan keputusan pimpinan saja.

Untuk mengetahui sejauh mana peranan Kerapatan Adat Nagari di Kenagarian Bukik Sikumpa Kabupaten Lima Puluh Kota , peneliti melakukan wawancara dengan anggota KAN Kenagarian Bukik Sikumpa Kabupaten Lima Puluh Kota tujuannya adalah untuk mengetahui sejauh mana peranan Kerapatan Adat Nagari di Kenagarian Bukik Sikumpa Kabupaten Lima Puluh.

Dari hasil keterangan anggota KAN tersebut bahwa terdapat empat bentuk masalah tanah ulayat di Kenagarian Bukik 
Sikumpa Kabupaten Lima Puluh Kota . Bila diurutkan dari yang paling sering terjadi adalah sebagai beikut:

1. Masalah/sengketa warisan tanah.

2. Bentuk kedua adalah masalah/sengketa batas-batas tanah ulayat.

3. Masalah/sengketa pemanfaatan tanah dan pembagian hasil.

4. Masalah/sengketa gadai dan atau jual beli tanah.

Namun dari bentuk-bentuk sengketa yang terjadi di Kenagarian Bukik Sikumpa Kabupaten Lima Puluh Kota, mayoritas masyarakat yang pernah mengalami sengketa tanah ulayat lebih memilih menyelesaikan dengan mengajukan ke instansi yang berwenang seperti pengadilan.

Maka disini disimpulkan sesuai keterangan dari beberapa orang masyarakat menunjukan peranan Kerapatan Adat Nagari dalam menyelesaikan masalah tanah ulayat sudah melemah, karena lebih cenderung memilih menyelesaikan masalah tanah ulayat melalui instansi yang berwenang dengan alasan bahwa memiliki kekuatan hukum tetap atau mengikat meskipun tentang penyelesaian sengketa pusaka tinggi agar terlebih dahulu melalui Kerapatan Adat Nagari, serta pada Pasal 12 dan 13 dalam Perda Nomor Tahun 2018 tentang Nagari menjelaskan bahwa:

Pasal 12

(1) Sengketa tanah ulayat di nagari diselesaikan oleh Kerapatan Adat Nagari menurut ketentuan sepanjang adat yang berlaku, "bajanjang naiak batanggo turun" dan diusahakan dengan jalan perdamaian melalui musyawarah dan mufakat dalam bentuk keputusan perdamaian.

(2) Apabila keputusan perdamaian tidak diterima oleh pihak yang bersengketa sebagaimana dimaksud pada ayat 1 maka pihakpihak yang bersengketa dapat mengajukan perkaranya ke pengadilan negeri.

(3) Keputusan Kerapatan Adat Nagari sebagaimana dimaksud pada ayat 1 dapat menjadi bahan pertimbangan hukum atau pedoman bagi hakim dalam mengambil keputusan.

Pasal 13

(1) Sengketa tanah ulayat antar nagari, diselesaikan oleh Kerapatan Adat Nagari antar nagari yang bersengketa, menurut ketentuan sepanjang adat yang berlaku secara musyawarah dan mufakat dalam bentuk perdamaian.

(2) Apabila tidak tercapai penyelesaian sebagaimana dimaksud pada ayat 1, maka pemerintah Kabupaten/Kota maupun Propinsi dapat diminta untuk menjadi mediator.

(3) Apabila tidak tercapai penyelesaiaan sebagaimana dimaksud pada ayat 2 , dapat mengajukan perkaranya ke pengdilan negeri.

Namun banyaknya hakim yang cenderung menerima perkara-perkara tersebut tanpa terlebih dahulu diselesaikan oleh Kerapatan Adat Nagari, semakin membuat masyarakat cenderung langsung 
memilih jalur pengadilan. Para hakim tersebut bepegangan pada UndangUndang Republik Indonesia Nomor 48 Tahun 2009 Tentang Kekuasaan Kehakiman pada Pasal 10 ayat (1), yaitu:

"Pengadilan dilarang menolak untuk memeriksa, mengadili, dan memutus suatu perkara yang diajukan dengan dalih bahwa hukum tidak ada atau kurang jelas, melainkan wajib untuk memeriksa dan mengadilinya."

Tidak hanya itu, dengan kurangnya sosialisasi Surat Edaran Pengadilan Tinggi yang menghimbau seluruh Pengadilan Negeri Sumatera Barat untuk menyelesaikan sengketa tanah ulayat terlebih dahulu harus melalui Kerapatan Adat Nagari, dianggap sebagai salah satu alasan kenapa masalah tanah ulayat dapat langsung diselesaikan ke Pengadilan Negeri tanpa melalui Kerapatan Adat Nagari. Hasil penyelesaian masalah tanah ulayat yang diselesaikan secara adat dianggap sering dan akan cenderung berat sebelah (hanya memuaskan salah satu pihak) serta dianggap tidak punya kekuatan hukum tetap atau mengikat membuat responden yang pernah mengalami masalah tanah ulayat cenderung tidak memilih menyelesaikan secara adat (Sri Yuardita, 2020).

Tidak semua masyarakat yang pernah mengalami masalah tanah ulayat menyelesaikan masalahnya melalui Kerapatan Adat Nagari, adanya masyarakat yang menyelesaikan sendiri secara musyawarah mufakat dan mengajukan ke instansi yang berwenang seperti pengadilan, menunjukkan bahwa kurang sebagian besar dari masyarakat kurang percaya terhadap peranan Kerapatan Adat Nagari sendiri (L. H. Sigiro, 2016)

Secara normatif Perda Sumbar tentang Tanah Ulayat dan Pemanfaatannya telah dengan tegas menyatakan bahwa lembaga Kerapatan Adat Nagari adalah lembaga mediasi adat yang memfasilitasi perdamaian bagi pihak-pihak yang bersengketa adat, namun dalam kenyataannya masih terdapat keputusan-keputusan Kerapatan Adat Nagari yang memutus sengketa adat yang bersifat mengadili. Kerapatan Adat Nagari dalam hal ini memposisikan lembaganya sebagai lembaga peradilan yang bisa memutuskan seperti halnya putusan yang diberikan oleh lembaga peradilan. Sebagai contoh adalah Kerapatan Adat Nagari yang menentukan kepemilikan suatu kaum atau orang perseorangan atas objek yang disengketakan, dan bukan lagi sebagai lembaga mediasi adat (Asmawati, 2014).

Selain tidak sesuai dengan maksud yang sebenarnya dari keberadaan Kerapatan Adat Nagari sebagai lembaga mediasi adat, keputusan Kerapatan Adat Nagari yang bersifat mengadili tersebut tidak mempunyai kekuatan hukum dan kekuatan eksekutorial. Belum tentu pihak yang dirugikan atau dikalahkan dengan sukarela melaksanakan keputusan Kerapatan Adat Nagari. Jika pihak yang dirugikan atau dikalahkan dengan keputusan Kerapatan Adat Nagari tidak dengan sukarela melaksanakan keputusan maka pihak yang diuntungkan atau 
dimenangkan tidak mendapat hak sebagaimana yang disebutkan dalam keputusan Kerapatan Adat Nagari karena lembaga Kerapatan Adat Nagari tidak memiliki kewenangan untuk melakukan eksekusi (R. Syarfina, 2019)

\section{Kendala Kerapatan Adat Nagari (KAN) dalam Menyelesaikan Sengketa Tanah ulayat di Kenagarian Bukik Sikumpa Kabupaten Lima Puluh Kota.}

Berdasarkan wawancara dengan Bapak Zulfakri Utama Putra sebagai Wali Nagari di Kenagarian Bukik Sikumpa Kabupaten Lima Puluh Kota mengenai kendala Kerapatan Adat Nagari (KAN) dalam menyelesaikan sengketa tanah ulayat di Kenagarian Bukik Sikumpa Kabupaten Lima Puluh Kota adalah sebagai berikut:

1. Kurangnya pengetahuan masyarakat (pihak yang bersengketa) tentang ketentuan hukum tanah ulayat kaum, menyebabkan sengketa diantara mereka susah untuk dicarikan penyelesaiannya.

2. Kurangnya kepercayaan anggota kaum terhadap ninik mamak mereka dan telah memudarnya peran dan tanggung jawab ninik mamak kepada kemenakannya dan terhadap tanah ulayat kaumnya (harta pusaka tingginya).

3. Penyelesaian yang dilakukan oleh Kerapatan Adat Nagari tidak cepat, jangka waktunya lama dan hampir sama dengan jangka waktu yang diselesaikan melalui Pengadilan juga di setiap mengadakan pertemuan harus menyediakan makanan dan minuman, sementara anggaran untuk itu tidak disediakan.

4. Kurangnya Pengetahuan anggota, hal ini dapat dilihat pada anggota KAN tersebut yang mahir dalam petatah dan petitih, tetapi dari segi keilmuan dalam menyelesaikan perkara masih kurang pada anggota KAN tersebut. KAN (Datuak Paduko Sati, 2020)

Hasil penyelesaian masalah tanah ulayat yang diselesaikan secara adat dianggap sering dan akan cenderung berat sebelah (hanya memuaskan salah satu pihak) serta dianggap tidak punya kekuatan hukum tetap atau mengikat membuat responden yang pernah mengalami masalah tanah ulayat cenderung tidak memilih menyelesaikan secara adat. Tidak semua masyarakat yang pernah mengalami masalah tanah ulayat menyelesaikan masalahnya melalui Kerapatan Adat Nagari, adanya masyarakat yang menyelesaikan sendiri secara musyawarah mufakat dan mengajukan ke instansi yang berwenang seperti pengadilan, menunjukkan bahwa kurang sebagian besar dari masyarakat kurang percaya terhadap peranan Kerapatan Adat Nagari sendiri. Masyarakat cenderung tidak percaya pada peranan Kerapatan Adat Nagari (dalam hal ini mengenai sengketa tanah ulayat), disebabkan oleh:

a. Kurangnya kepercayaan dari masyarakat terhadap peranan Kerapatan Adat Nagari dalam menyelesaikan masalah atau sengketa tanah akan dilakukan secara adil, dan 
penyelesaian tersebut dapat memberi kepastian hukum.

b. Penyelesaian yang dilakukan oleh Kerapatan Adat Nagari tidak mempunyai kekuatan mengikat, antara lain seperti sanksi apabila salah satu pihak melanggar kesepakatan yang telah dibuat.

c. Penyelesaian yang dilakukan oleh Kerapatan Adat Nagari tidak cepat, jangka waktunya lama dan hampir sama dengan jangka waktu yang diselesaikan melalui Pengadilan, tidak mudah karena prosesnya bertingkat dan tidak murah karena setiap mengadakan pertemuan harus menyediakan makanan dan minuman (M. Nazir, 1998).

Seperti yang dijelaskan pada sub-bab sebelumnya, salah satu yang menyebabkan melemahnya peranan Kerapatan Adat Nagari adalah kurang berperannya para ninik mamak yang ada Kenagarian Bukik Sikumpa Kabupaten Lima Puluh Kota. Hampir sebagian besar Datuk-Datuk di Kenagarian Bukik Sikumpa Kabupaten Lima Puluh Kota tidak berdomisili di daerah tersebut, yang ada justru hanya para wakil dari masingmasing datuk saja serta kurang pedulinya para ninik mamak yang ada di rantau terhadap kemenakannya. Hal ini membuat melemahnya peran ninik mamak dalam hal pengawasan terhadap kaumnya. Karena jauhnya jarak antara para ninik mamak dan kemenakannya menyebabkan para ninik mamak tersebut tidak mengetahui permasalahan- permasalahan yang dialami oleh kemenakannya.
Tidak hanya itu, kurang pedulinya para ninik mamak yang berada di rantau membuat para kemenakan atau kaumnya yang bersengketa mengambil jalur penyelesaiannya sendiri tanpa merundingkan dengan para ninik mamaknya, baik itu langsung menyelesaikan melalui pengadilan ataupun cara penyelesaian lainnya. Hal ini menyebabkan permasalahan yang seharusnya dapat diselesaikan secara kekeluargaan menjadi besar hingga bisa diajukan ke pengadilan.

Melemahnya peran ninik mamak juga mengakibatkan melemahnya peranan Kerapatan Adat Nagari (KAN) di Kenagarian Bukik Sikumpa Kabupaten Lima Puluh Kota tersebut. Melemahnya Kerapatan Adat Nagari juga dikarenakan adanya perubahan pada masyarakat disana. Bila dahulu masyarakat nya bersifat komunal, sekarang sudah mulai mengalami perubahan yaitu menjadi individual. Masyarakat disana sudah banyak yang hanya mulai memikirkan diri sendiri. Sehingga hukum adat pun lama kelamaan mulai melemah.

Salah satu bukti bahwa sistem adat mulai mengalami penurunan adalah banyaknya ditemukan penyelesaian sengketa melalui pengadilan, yang juga berdampak pada peranan Kerapatan Adat Nagari.

Peran ninik mamak yang terpecah Niniak mamak menjadi unsur dalam KAN. Niniak mamak juga dapat menimbulkan perpecahan, ada niniak mamak yang pro pada pihak lain dan ada pula niniak mamak yang pro pada anak 
Faisal: Peran Kerapatan Adat Nagari (KAN) Dalam Menyelesaikan Sengketa Tanah Ulayat

kemenakannya. Dalam proses penyelesaian sengketa tersebut sulit dibedakan mana niniak mamak yang benar-benar mendukung kemenakannya.Juga kendala lainnya tentang pengetahuan prosedur hukum/adat yang rendah Wawasan yang kurang tentang bagaimana prosedur hukum atau adat yang benar yang harus ditempuh (Arwana, Y. C., \& Arifin, R. 2019).

Berdasarkan wawancara dengan Datuak Paduko Rajo sebagai anggota KAN di Kenagarian Bukik Sikumpa Kabupaten Lima Puluh Kota mengenai Upaya Kerapatan Adat Nagari (KAN) untuk Mengatasi Kendala dalam Menyelesaikan Sengketa Tanah Ulayat di Kenagarian Bukik Sikumpa Kabupaten Lima Puluh Kota adalah sebagai berikut:

1. Meningkatkan pengetahuan masyarakat (pihak yang bersengketa) tentang ketentuan hukum tanah ulayat kaum, dengan cara memberikan penjelasan-penjelasan dan menyediakan waktu untuk berkonsultasi dengan pemuka adat, sehingga mereka yang bersengketa tersebut paham tentang ketentuan hukum tanah ulayat kaum.

2. Meningkatkan kepercayaan anggota kaum terhadap ninik mamak mereka terhadap telah memudarnya peran dan tanggung jawab ninik mamak kepada kemenakannya mengenai tanah ulayat kaumnya (harta pusaka tingginya) dengan cara lebih meningkatkan silaturahmi dan juga sering bertukar pikiran dengan ninik mamak, sehingga kepercayaan terhadap ninik mamak juga semakin meningkat.

3. Karena pada kenyataannya penyelesaian yang dilakukan oleh Kerapatan Adat Nagari tidak cepat, jangka waktunya lama dan hampir sama dengan jangka waktu yang diselesaikan melalui Pengadilan maka sebagai solusinya setiap sengketa tanah ulayat yang dipersengketakan tersebut di beri jangka waktu untuk diselesaikan secara cepat dan tepat dan anggota KAN lebih fokus dan lebih serius terhadap proses penyelesaiannya, juga di setiap mengadakan pertemuan harus menyediakan makanan dan minuman, maka dibuatkan anggaran untuk hal itu .

\section{SIMPULAN}

Berdasarkan pada hasil penelitian dan pembahasan yang penulis buat dan penulis lakukan, maka penulis menyimpulkan sebagai berikut:

1. Peran KAN Bukik Sikumpa Kabupaten Lima Puluh Kota, adalah sebagai penengah atas setiap sengketa berdasarkan ketentuan Perda Nomor 7 tahun 2018 Tentang Nagari dimana langkah-langkah penyelesaian sengketa tanah ulayat wajib didahului dengan musyawarah di tingkat keluarga, kaum, dan pesukuan. KAN dapat bertindak sebagai penengah dalam menyelesaikan sengketa apabila ketiga langkah tersbut telah di tempuh para keluarga yang bersengketa. Tapi kenyataannya 
dalam peran tersebut ditemui kendala-kendala.

2. Kendal-kendala tersebut adalah: kurangnya pengetahuan masyarakat (pihak yang bersengketa) tentang ketentuan hukum tanah ulayat kaum, Kurangnya kepercayaan anggota kaum terhadap ninik mamak mereka dan penyelesaian yang dilakukan oleh Kerapatan Adat Nagari tidak cepat, jangka waktunya lama dan hampir sama dengan jangka waktu yang diselesaikan melalui Pengadilan juga di setiap mengadakan pertemuan harus menyediakan makanan dan minuman, sementara anggaran untuk itu tidak disediakan dan juga kurangngya pengetahuan anggota KAN, maka upaya yang dilakukan adalah: meningkatkan pengetahuan masyarakat (pihak yang bersengketa) tentang ketentuan hukum tanah ulayat kaum, dengan cara memberikan penjelasan-penjelasan dan menyediakan waktu untuk berkonsultasi dengan pemuka adat, meningkatkan kepercayaan anggota kaum terhadap ninik mamak mereka terhadap telah memudarnya peran dan tanggung jawab ninik mamak kepada kemenakannya cara lebih meningkatkan silaturahmi dan juga sering bertukar pikiran dengan ninik mamak, sehingga kepercayaan terhadap ninik mamak juga semakin meningkat dan sengketa tanah ulayat yang dipersengketakan tersebut di beri jangka waktu untuk diselesaikan secara cepat dan tepat dan anggota KAN lebih fokus dan lebih serius terhadap proses penyelesaiannya, juga di setiap mengadakan pertemuan harus menyediakan makanan dan minuman, maka dibuatkan anggaran untuk hal itu. Dan menambah pengetahuan anggota KAN dengan meningkatkan pendidikan ( S 1 dan S 2terutama dibidang Hukum), mengikuti pelatihan-pelatihanseminar-seminar dan Bimtek.

\section{UCAPAN TERIMA KASIH}

Puji dan Syukur penulis ucapkan ke hadirat Allah SWT yang telah memberikan Rahmat dan Karunia-Nya, sehingga akhirnya penulis dapat menyelesaikan penulisan karya ilmiah ini yang berjudul: "Peran Kerapatan Adat Nagari (KAN) dalam Menyelesaikan sengketa Tanah Ulayat.

Sebagai manusia biasa penulis menyadari bahwa dalam penulisan dan penyajian karya ilmiah ini masih banyak kekurangan dan jauh dari kesempurnaan bila ditinjau dari segi ilmiah maupun tata bahasa, yang disebabkan karena keterbatasan kemampuan yang penulis miliki. Penulis menyadari bahwa tanpa bantuan dan dorongan dari berbagai pihak tidak mungkin karya ilmiah ini dapat diselesaikan. Oleh karena itu pada kesempatan ini dengan segala kerendahan hati, penulis ingin mengucapkan terimakasih dan penghargaan yang sebesar-besarnya kepada:

1. Bapak Dr. Eviandi Ibrahim S.H., M.Hum selaku Ketua Sekolah Tinggi Ilmu Hukum Putri Maharaja Payakumbuh. 
Faisal: Peran Kerapatan Adat Nagari (KAN) Dalam Menyelesaikan Sengketa Tanah Ulayat

2. Bapak Rahmat Fauzi SHI MA sebagai ketua LPPM Sekolah Tinggi Ilmu Hukum Putri Maharaja Payakumbuh.

\section{DAFTAR PUSTAKA}

H. Idurs Hakimi Dt. R. Penghulu. (2013). Pokok-pokok Pengetahuan Adat Alam Minangkabau, Sekretariat LKAAM, Sumbar

Nurullah. (1999). Tanah Ulayat Menurut Ajaran Adat Minangkabau, PT. Singgalang Press, Padang.

M. Nazir. (1998). Hukum Acara Adat Dalam Perkara Penyelesaian Sengketa Tanah, Diklat, Padang

A.A. Navis. (1994). Alam Terkembang Jadi Guru, Adat dan Kebudayaan Minangkabau, Penerbit PT. Grafiti, Jakarta

Shrimanti Indira Pratiwi. (2019). Penyelesaian Sengketa Tanak Ulayat antara masyarakat Hukum, Jurnal Hukum, Vol.4 No. 1, hal. 2845;

Titin Fatimah dan Hengki Andora. (2018). Pola Penyelesaian Sengketa Tanah Ulayat di Sumatera Barat, Jurnal Ilmu Hukum, Vol.4. No. 1, Hal. 40-75

Amran. (2017). Penyelesaian Sengketa Tanah Ulayat melalui lembaga adat di Minang Kabau Sumatera Barat, Jurnal Hukum Acara Perdata, Vol. 3 No.2, Hal.1-19

Ahyuni Yunusdan Ahmad Ali Muddin. (2019). Penyelesaian Sengketa Tanah Ulayat Yang Telah Bersertifikat, Jurnal Kertha Patrika, Vol. 41 No.3, Hal. 15-35
Sri Yuardita. (2020). Sengketa Pemanfaatan Tanah Ulayat kaum dalam suku Caniago di Kecamatan Lubuk Kilangan Kota Padang, Journal Ilmu Hukum Vol. 2 No. 1, Hal. 45-60

Arwana, Y. C., \& Arifin, R. (2019). Jalur Mediasi dalam Penyelesaian Sengketa Pertanahan Sebagai Dorongan Pemenuhan Hak Asasi Manusia. JALREV (Jambura Law Review), 1(2), 212236. https://doi.org/https://doi.org/1 0.33756/jalrev.v1i2.2399

Asmawati. (2014). Mediasi Salah Satu Cara dalam Penyelesaian Sengketa Pertanahan. Jurnal Ilmu Hukum, 1, 54-66.

Retrieved from https://media.neliti.com/media /publications/43283-ID-mediasisalah-satu-cara-dalam-penyelesaiansengketa-pertanahan.pdf

Nova Yarsina. (2018). Perlindungan Hukum Terhadap Tanah Ulayat Yang Telah Bersertifikat, di Kota Bukittinggi, Jurnal Cendekia Hukum: Vol. 3, No 2, Maret 2018, Hal.166-175

Ratih Agustin Wulandari, Muhammad Sukron, Raimon Efendi. (2020). Analisa Hukum Peralihan Hak Tanah Ulayat kaunm yang belum di Daftarkan di Kabupaten Dhamasraya, Jurnal Cendekia Hukum: Vol. 6, No 1, September 2020, Hal. 61-71

L. H. Sigiro. (2016). "Analisis Hukum Tentang Pendaftaran Tanah Ulayat yang Menjadi Hak Perorangan Pada Tanah Ulayat di Kabupaten 
Jurnal Cendekia Hukum: Vol. 6, No 2, Maret 2021

Dairi," Premise Law J., vol. 17, 2016.

S. R. Fatmi and U. Jember. (2018). Permohonan Tanah Ulayat di Minangkabau Menjadi Tanah Hak Milik, Lentera Huk., vol. 5, no. 3, pp. 392-407, 2018, doi: 10.19184/ejlh.v5i3.8291.
R. Syarfina. (2019). Pengaruh Hukum Adat Dalam Proses Peralihan Hak Tanah Ulayat Pada Pembangunan Perluasan Bandara Di Jayapura, Otentik's J. Huk. Kenotariatan, vol. 1, no. 1, pp. 47-53, 2019. 